\title{
Artikel
}

\section{Het Nederlandse stelsel van rechtsbescherming tegen plannen en programma's getoetst}

\author{
Over het belang van het Verdrag van Aarhus en het Unierecht
}

\author{
Mr. E.J.H. (Ernst) Plambeck*
}

\section{Inleiding}

In deze bijdrage, die een weerslag biedt van de door Lorenzo Squintani gehouden presentatie tijdens de VMR-bijeenkomst op 31 mei 2018, ${ }^{1}$ staat de vraag centraal welke eisen het internationaal en Unierecht stellen aan rechtsbescherming tegen plannen en programma's in het omgevingsrecht, en in hoeverre Nederland daaraan voldoet. Ter beantwoording van deze vraag wordt eerst het Verdrag van Aarhus en de implementatie daarvan in het Unierecht bekeken, waarbij ook de reikwijdte van het begrip 'plannen en programma's' in het EUmilieurecht wordt geschetst. Daarna wordt ingegaan op de toetsing overeenkomstig het Unierecht en de (on)mogelijkheid van exceptieve toetsing. Dit wordt gevolgd door een analyse van het Nederlandse rechtssysteem, waarna geconcludeerd wordt dat dit rechtssysteem op onderdelen tekort lijkt te schieten, gelet op het internationaal en Unierecht.

Mr. E.J.H. Plambeck is adviseur bestuursrecht bij Koninklijke Metaalunie en daarnaast als promovendus verbonden aan het Utrecht Centre for Water, Oceans and Sustainability Law van de Universiteit Utrecht. Deze bijdrage is afgesloten op 6 oktober 2018.

1. De presentatie en dit artikel vormen het resultaat van gezamenlijk onderzoek van schrijver dezes en Lorenzo Squintani, universitair docent Europees en economisch recht aan de Rijksuniversiteit Groningen.

\section{Verdrag van Aarhus en Unierechtelijke implementatie}

\subsection{Toegang tot de rechter}

Het welbekende Verdrag van Aarhus ${ }^{2}$ (hierna: Verdrag) stelt onder meer eisen aan rechtsbescherming in het omgevingsrecht. Aangezien Nederland en de Europese Unie beide partij zijn bij dit Verdrag, betekent dit voor de Europese Unie dat de bepalingen uit dit Verdrag voorrang hebben boven het secundaire Unierecht. ${ }^{3}$ Voor Nederland betekent dit enerzijds dat het Verdrag, voor zover het is omgezet in een specifieke bepaling in het secundaire Unierecht, via het Unierecht doorwerkt. ${ }^{4}$ Anderzijds hebben verdragsbepalingen die niet zijn omgezet in het Unierecht voorrang boven daarmee strijdig nationaal recht en dient het nationaal recht verdragsconform te worden uitgelegd of buiten toepassing te worden gelaten. ${ }^{5} \mathrm{Om}$ het doel van het Verdrag ${ }^{6}$ te

2. Verdrag betreffende toegang tot informatie, inspraak bij besluitvorming en toegang tot de rechter inzake milieuaangelegenheden, Trb. 2001, 73.

3. Art. 216, tweede lid, VWEU

4. J.M.I.J. Zijlmans, De doorwerking van natuurbeschermingsverdragen in de Europese en Nederlandse rechtsorde, Den Haag: Sdu Uitgevers 2011, p. 45; zie ook HvJ EU 8 maart 2011, C-240/09, ECLI:EU:C: 2011:125 (Zoskupenie I).

5. Zijlmans 2011, p. 49; zie ook de Zoskupenie I-uitspraak en HvJ EU 20 december 2017, C-664/15, ECLI:EU:C:2017:987 (Protect Natur).

6. Neergelegd in art. 1 Verdrag. 
verwezenlijken moeten partijen ingevolge art. 9, tweede respectievelijk derde lid, in samenhang bezien met art. 6 respectievelijk 7, van het Verdrag toegang tot de rechter verzekeren. Daarbij moet aan de in art. 9, vierde lid, van het Verdrag neergelegde vereisten worden voldaan.

Hoewel er verschil bestaat ten aanzien van de discretionaire ruimte tussen art. 9, tweede en derde lid, Verdrag en degenen die toegang moeten hebben tot de rechter, staat vast dat er in ieder geval effectieve rechtsbeschermingsmechanismen beschikbaar moeten zijn. ${ }^{7}$ Veel elementen van de procedures, zoals locu standi, kosten en bewijslast, mogen Verdragspartijen zelf bepalen. ${ }^{8}$ Deze ruimte wordt echter begrensd door het doel van het Verdrag, zoals neergelegd in de preambule en art. $1 \mathrm{t} / \mathrm{m}$ $3,{ }^{9}$ met name dat 'effective judicial mechanisms should be accessible to the public, including organizations, so that its legitimate interests are protected and the law is enforced'. ${ }^{10}$ Of rechtsbescherming wordt geboden via strafrecht, privaatrecht of bestuursrecht doet daarbij niet ter zake. ${ }^{11} \mathrm{Wel}$ is, aldus de Aarhus Convention Compliance Committee (ACCC), het gehele stelsel van rechtsbescherming in een land, zowel naar de letter als naar de praktijk, van belang. ${ }^{12}$

\subsection{Objectum litis}

De vraag rijst wat ingevolge het Verdrag aan de rechter moet kunnen worden voorgelegd. Ingevolge art. 9, tweede lid, jo. art. 6 van het Verdrag moeten aan een rechter zowel besluiten waarbij al dan niet toestemming wordt verleend voor activiteiten als opgenomen in bijlage I van het Verdrag, als besluiten die zien op andere activiteiten die een significant effect kunnen hebben op het milieu, kunnen worden voorgelegd. Ingevolge art. 9, derde lid, jo. art. 7 van het Verdrag moeten ook plannen en programma's betrekking hebbende op het milieu aan een rechterlijke toetsing kunnen worden onderworpen. Als onderdelen van een plan of programma qua inhoud betrekking hebben op specifieke activiteiten, dan is wat

7. Belgium ACCC/2005/11; ECE/MP.PP/C.1/2006/4/Add.2, 28 juli 2006

8. Voor de verplichtingen die gelden ten aanzien van verschillende procedurele aspecten, zie A. Andrusevych \& S. Kern (red.), Case Law of the Aarhus Convention Compliance Committee (2004-2014), Lviv: RACSE 2016, p. 101-140. Bijv. toegang tot de rechter onder art. 9, derde lid, Verdrag moet de regel en niet de uitzondering zijn, zie Belgium ACCC/ 2005/11; ECE/MP.PP/C.1/2006/4/Add.2, 28 juli 2006, par. 36.

9. Belgium ACCC/2005/11; ECE/MP.PP/C.1/2006/4/Add.2, 28 juli 2006, par. 34.

10. Preambule van het Verdrag, par. 18. Voor de toepassing hiervan door de ACCC, zie bijv. Bulgaria ACCC/C/2011/58; ECE/MP.PP/C. 1/2013/4, 11 januari 2013, par. 52 en Germany ACCC/C/2008/31; ECE/MP.PP/C.1/2014/8, 4 juni 2014, par. 64.

11. Zie Denmark ACCC/C/2006/18; ECE/MP.PP/2008/5/Add.4, 29 april 2008, par. 32.

12. Germany ACCC/C/2008/31; ECE/MP.PP/C.1/2014/8, 4 juni 2014, par. 65. betreft rechtsbescherming daarop art. 9, tweede lid, van het Verdrag van toepassing, aldus de ACCC. ${ }^{13}$

Wat is een plan of programma? In het Verdrag zelf wordt dit niet gedefinieerd, omdat het vanzelfsprekend werd geacht wat daaronder moet worden verstaan. ${ }^{14}$ In specifieke Unierichtlijnen worden wel plannen en programma's voorgeschreven, maar ontbreekt veelal een definitie. ${ }^{15}$ Slechts de SMB-richtlijn bevat een definitie. Kortweg gaat het om plannen en programma's die door een instantie op nationaal, regionaal of lokaal niveau worden opgesteld en/of vastgesteld, of die door een instantie worden opgesteld om middels een wetgevingsprocedure door het parlement of de regering te worden vastgesteld, en die door wettelijke of bestuursrechtelijke bepalingen zijn voorgeschreven. Zoals toegelicht door het Hof van Justitie, dient een dergelijk vastgesteld document de criteria en de regels in verband met de ruimtelijke ordening dan wel de luchtkwaliteit, waterkwaliteit of afvalstoffen vast te stellen en te voorzien in toezichtregels en -procedures die bij de uitvoering van één of meer projecten in acht moeten worden genomen. ${ }^{16}$ Daarnaast valt onder de definitie 'iedere handeling die, door vaststelling van op de betrokken sector toepasselijke regels en controleprocedures, een heel pakket criteria en modaliteiten vaststelt voor de goedkeuring en de uitvoering van één of meerdere projecten die aanzienlijke gevolgen voor het milieu kunnen hebben'. ${ }^{17}$

\subsection{Unierechtelijke omzetting}

Met de wijziging van de Mer-richtlijn en de Richtlijn Industriële Emissies (RIE) heeft de Europese Unie beoogd art. 9, tweede lid, van het Verdrag om te zetten. ${ }^{18}$ Wat art. 9, derde lid, van het Verdrag betreft is een voorstel voor een algemene richtlijn over rechtsbe-

13. ACCC 10 mei 2006, Armenia, ACCC/C/2004/8; ECE/MP.PP/C. 1/2006/2/Add.1, par. 28; ACCC 11 januari 2013, Bulgaria, ACCC/C/ 2011/58; ECE/MP.PP/C.1/2013/4, par. 53. Zie ook J. Jendrośka, Public Participation in the Preparation of Plans and Programs: Some Reflections on the Scope of Obligations under Article 7 of the Aarhus Convention, Journal for European Environmental \& Planning Law 2009, afl. 4, p. $495-515$.

14. Zie ook United Nations Economic Commission for Europe, The Aarhus Convention. An Implementation Guide, 2014, p. 173 e.v.

15. Gewezen kan worden op art. 13 Kaderrichtlijn water, art. 23 Richtlijn luchtkwaliteit en art. 28 Afvalstoffenrichtlijn.

16. HvJ EU 22 maart 2012, C-567/10, ECLI:EU:C:2012:159 (Inter-Environnement Bruxelles e.a.), r.o. 30; HvJ EU 11 september 2012, C-43/10, ECLI:EU:C:2012:560 (Nomarchiaki Aftodioikisi Aitoloakarnanias e.a.).

17. HvJ EU 27 oktober 2016, C-290/15, ECLI:EU:C:2016:816 (Patrice D'Oultremont e.a./Région wallonne), r.o. 49; HvJ EU 11 september 2012, C-43/10, ECLI:EU:C:2012:560 (Nomarchiaki Aftodioikisi Aitoloakarnanias e.a.), r.o. 95.

18. Richtlijn 2003/35/EG van het Europees Parlement en de Raad van 26 mei 2003 tot voorziening in inspraak van het publiek in de opstelling van bepaalde plannen en programma's betreffende het milieu en, met betrekking tot inspraak van het publiek en toegang tot de rechter, tot wijziging van de Richtlijnen 85/337/EEG en 96/61/EG van de Raad Verklaring van de Commissie, PbEG 2003, L 156/17 (de zogenoemde Aarhusrichtlijn); en Verordening (EG) nr. 1367/2006 van het Europees Parlement en de Raad van 6 september 2006 betreffende de toepassing van de bepalingen van het Verdrag van Aarhus betreffende toegang tot informatie, inspraak bij besluitvorming en toegang tot de rechter inzake milieuaangelegenheden op de communautaire instellingen en organen, PbEG 2006, L 264/13. 
scherming ingetrokken. ${ }^{19}$ Geen van de Unierichtlijnen die lidstaten verplichten om plannen en programma's op te stellen om het milieu te beschermen, vereist dat dergelijke plannen en programma's aan een rechter kunnen worden voorgelegd. Zelfs de SMB-richtlijn stelt een dergelijke eis niet. De Aarhusrichtlijn en andere specifieke richtlijnen, zoals de Kaderrichtlijn water (KRW), doen dit evenmin. Dit geldt ook voor (onderdelen van) plannen en programma's die onder art. 9, tweede lid, van het Verdrag vallen en niet onder de Mer-richtlijn of RIE. $^{20}$

Echter, het Hof van Justitie heeft voor plannen en programma's die zien op natuurbescherming geoordeeld dat mede gelet op art. 19, eerste lid, van het Verdrag betreffende de Europese Unie (VEU) jo. art. $47 \mathrm{EU}-$ Handvest nationale rechters het nationaal recht conform art. 9, derde lid, van het Verdrag dienen uit te leggen, ${ }^{21}$ en als verdragsconforme interpretatie niet mogelijk is, nationale bepalingen buiten toepassing te laten. ${ }^{22} \mathrm{Het}$ adagium ubi ius, ibi remedium ligt daaraan ten grondslag, oftewel: waar een recht is op milieubescherming, daar moet ook toegang tot de rechter mogelijk zijn om dit recht te verzekeren. ${ }^{23}$ Ditzelfde adagium klinkt door in de Janecek- en RWE-zaken, waarin het Hof van Justitie ten aanzien van actieplannen ter verbetering van de luchtkwaliteit respectievelijk reductieprogramma's in het kader van de NEC-richtlijn heeft geoordeeld dat deze aan een rechter moeten kunnen worden voorgelegd. ${ }^{24} \mathrm{Om}$ die reden is het zeer waarschijnlijk dat het primaire Unierecht, in ieder geval ten aanzien van plannen en programma's die zien op luchtkwaliteit en natuurbescherming, vereist dat deze kunnen worden voorgelegd aan een rechter. Omdat zowel de luchtkwaliteitsrichtlijnen als de KRW uitgaan van een doelgerichte aanpak en gebruik maken van plannen en programma's om de gestelde doelen te bereiken, lijkt de verplichting ook ten aanzien van het Uniewaterrecht te gelden. ${ }^{25}$ Verder kan niet worden uitgesloten dat deze verplichting ook geldt voor andere milieugebieden, zoals het EU-klimaatveranderingsrecht. Dit vergt echter nader onderzoek. In ieder geval zou, in het licht van het Verdrag, voor art. 19, eerste lid, VEU en art. 47 EU-Handvest een dergelijke analogie wenselijk zijn.

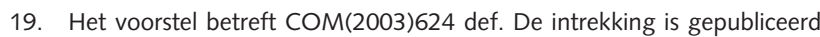
in PbEU 2014, C 153/3. Zie verder M. Hedemann-Robinson, Enforcement of European Union Environmental Law. Legal Issues and Challenges, Abingdon, UK: Routledge 2015, p. 391 e.v.

20. Deze twee richtlijnen hebben art. 9, tweede lid, Verdrag min of meer letterlijk overgenomen.

21. Zoskupenie I-uitspraak, r.o. 51. Zie ook HvJ EU 15 maart 2018, C-470/16, ECLI:EU:C:2018:185 (North East Pylon).

22. HvJ EU 20 december 2017, C-664/15, ECLI:EU:C:2017:987 (Protect Natur).

23. HvJ EU 8 november 2016, C-243/15, ECLI:EU:C:2016:838 (Zoskupenie II).

24. Zie HvJ EG 25 juli 2008, C-237/07, ECLI:EU:C:2008:447 (Janecek/Freistaat Bayern), respectievelijk HvJ EU 26 mei 2011, C-165/09 t/m C-167/09, ECLI:EU:C:2011:348 (RWE), r.o. 100

25. Zie ook J. Ebbesson, Access to Justice at the National Level. Impact of the Aarhus Convention and European Union Law, in: M. Pallemaerts (red.), The Aarhus Convention at Ten, Groningen: Europa Law Publishing 2011, p. 265.
Zoals algemeen bekend, moeten lidstaten Unierechtelijke verplichtingen, ook nu deze volgens het Hof van Justitie voortvloeien uit het primaire Unierecht, zodanig implementeren dat rechtszekerheid wordt geboden. ${ }^{26}$ Dat wil in dit geval zeggen dat lidstaten een duidelijk en effectief stelsel voor rechtsbescherming moeten bieden, gelet op art. 9, tweede, derde en vierde lid, Verdrag jo. art. 19, eerste lid, VEU jo. art. 47 EU-Handvest, en tevens op de bepalingen in het secundaire Unierecht die lidstaten verplichten om plannen en programma's op te stellen. $^{27}$

\subsection{Eisen aan toetsing}

$\mathrm{Nu}$ duidelijk is dat het Verdrag en het Unierecht vereisen dat plannen en programma's aan een rechter moeten kunnen worden voorgelegd, is het onder meer de vraag welke wijze van toetsing voldoet aan het Verdrag en het Unierecht. De overige eisen die voortvloeien uit art. 9, vierde lid, Verdrag, zoals tijdigheid, betaalbaarheid en toegankelijkheid van (in het bijzonder de civiele) rechtspraak, blijven buiten beschouwing. De vraag is of plannen en programma's als zodanig rechtstreeks aan de rechter moeten kunnen worden voorgelegd, of dat exceptieve toetsing volstaat.

Als het Verdrag en de Unierechtelijke implementatie worden geinterpreteerd overeenkomstig Unierechtelijke methodes, dan is de meest waarschijnlijke conclusie dat plannen en programma's rechtstreeks aan de rechter moeten kunnen worden voorgelegd. De gangbare wijze van interpretatie die het Hof van Justitie, evenals de ACCC, hanteert, is de teleologische interpretatie, ondersteund door systematische interpretatie, binnen de grenzen van de tekst van de te interpreteren bepaling. ${ }^{28}$ In het kader van het Unierecht geldt bovendien dat in het geval een Unierechtelijke bepaling vatbaar is voor meerdere interpretaties, de voorkeur dient te worden gegeven aan die interpretatie die de hoogste mate van zekerheid biedt om de doeltreffendheid van het Unierecht te verzekeren. ${ }^{29}$

\section{- $\quad$ Teleologische interpretatie}

Het overkoepelende doel van het Verdrag, namelijk dat iedereen het recht heeft om te leven in een gezond milieu en de verplichting heeft om het milieu te beschermen en te verbeteren voor huidige en toekomstige generaties, waaruit het voorzorgsbeginsel, het preventiebeginsel en het beginsel dat vervuiling aan de bron dient te worden bestreden voortvloeien, onderstreept het belang om grondig en zo snel mogelijk aantasting van het milieu aan te pakken. Dit verhoudt zich minder goed met het

26. HvJ EG 30 mei 1991, C-361/88, ECLI:EU:C:1991:224 (TA Luft).

27. Zie L. Squintani \& E.J.H. Plambeck, Judicial Protection against Plans and Programmes Affecting the Environment - A Backdoor Solution to Get an Answer from Luxembourg, Journal for European Environmental \& Planning Law 2016, afl. 3-4, p. 294-324; K. Lenaerts \& J.A. GutiérrezFons, The General System of EU Environmental Law Enforcement, Yearbook of European Law 2011, p. 35-36.

28. Bijv. HvJ EG 7 maart 1985, 32/84, ECLI:EU:C:1985:104 (Van Gend \& Loos). Zie ook art. 31 Weens Verdragenverdrag, UNTS 1980 I-18232.

29. Bijv. HvJ EG 24 februari 2000, C-434/97, ECLI:EU:C:2000:98 (Commissie/Frankrijk), r.o. 21 HvJ EG 22 september 1988, 187/87, ECLI:EU:C:1988:439 (Land de Sarre e.a.), r.o. 19. 
aanvechten van een plan of programma over de band van een specifieke handeling gebaseerd op een plan of programma. Exceptieve toetsing leidt dan tot vertraging in het bereiken van het doel. Dit geldt te meer in die gevallen waarin geen specifieke besluiten nodig zijn om activiteiten te ontplooien op basis van de plannen en programma's.

\section{- $\quad$ Systematische interpretatie}

Binnen de systematiek van het Verdrag geldt dat rechtsbescherming een cruciale rol speelt in het effectueren van het recht op doeltreffende participatie. ${ }^{30}$ Daarom kan worden gesteld dat zonder rechtsbescherming jegens plannen en programma's als zodanig het recht om doeltreffend te kunnen participeren in het kader van de voorbereiding en vaststelling van plannen en programma's tot een lege huls verwordt, omdat individuen het door partijen niet naleven van art. 7 van het Verdrag niet aan een rechter kunnen voorleggen. Ook de Europese Commissie lijkt van mening dat exceptieve toetsing onvoldoende is om procedurele rechten bij plannen en programma's te waarborgen. ${ }^{31}$ Daarbij wijst de Commissie op een analoge toepassing van de ratio in de Kraaijeveld-uitspraak, ${ }^{32}$ oftewel het adagium $u b i$ ius, ibi remedium.

\section{- $\quad$ Tekstuele interpretatie}

Ten slotte zijn de bewoordingen van art. 9, derde lid, van het Verdrag relevant. ${ }^{33}$ Deze bepaling is van toepassing op, onder andere, 'acts of public authorities'. Plannen en programma's vallen onder 'acts of public authorities'. Hoewel men kan stellen dat slechts die handelingen aan rechterlijke toetsing onderworpen moeten worden die het milieu daadwerkelijk aantasten, waarbij plannen en programma's meestal kaderstellend zijn voor die nadere handelingen, wordt daarmee geen recht gedaan aan het bepaalde in art. 9, derde lid, van het Verdrag, namelijk 'which contravene provisions of its national law relating to the environment'. Alleen een rechtmatigheidstoets is relevant onder art. 9, derde lid, van het Verdrag. Dit betekent dat, zoals bijvoorbeeld volgt uit art. 6, eerste lid, van de Habitatrichtlijn, dat omdat natuurbeheerplannen moeten bijdragen aan het behoud en de verbetering van de instandhoudingsdoelstellingen van een Natura 2000-gebied, dergelijke plan-

30. Zie United Nations Economic Commission for Europe 2014, p. 187; H. Lang, Public Participation in Environmental Decision-Making in China (diss. Groningen), 2014, hoofdstuk 3 en J. Jendrośka, Public Participation under Article 6 of the Aarhus Convention: Role in Tiered DecisionMaking and Scope of Application, in: G. Bándi (red.), Environmental Democracy and Law. Public Participation in Europe, Groningen: Europa Law Publishing 2014, p. 113-138. Zie ook E.J.H. Plambeck, Paradoxes of the EU Regulatory Framework in Water Management: Developing an Assessment Framework to Put the Governance Approach to the Test, Water Law 2015, afl. 5-6, p. 272-280.

31. Notice on Access to Justice in Environmental Matters, C(2017)2616 final, par. 96-100. Zie ook de paragrafen over het beschermen van materiële rechten (par. 62 en section $2.5 c$ ), althans op een meer impliciete wijze.

32. HvJ EG 23 mei 1996, C-72/95, ECLI:EU:C:1996:204 (Kraaijeveld), r.o. 56.

33. Omwille van de leesbaarheid blijft vermelding van art. 9, tweede lid, Verdrag achterwege. nen geen maatregelen kunnen bevatten die het tegenovergestelde resultaat bewerkstelligen. ${ }^{34}$ Het feit dat pas nadat dergelijke maatregelen daadwerkelijk zijn goedgekeurd en/of getroffen het milieu wordt aangetast, doet vanwege de rechtmatigheidstoets juridisch niet ter zake. Exceptieve toetsing lijkt dan ook moeilijk verenigbaar met de rechtmatigheidstoets als geformuleerd in art. 9, derde lid, van het Verdrag.

\subsection{Tussenconclusie}

Kortom, het Hof heeft expliciet de koppeling tussen enerzijds rechtsbescherming en anderzijds publieke participatie en een hoog niveau van milieubescherming erkend. ${ }^{35}$ Zoals aangegeven, is het niet waarschijnlijk dat louter exceptieve toetsing voldoet aan het Verdrag. Hoewel niet kan worden gesteld dat exceptieve toetsing per definitie in strijd is met het Verdrag en het Unierecht, belemmert exceptieve toetsing ten opzichte van rechtstreekse toetsing wel meer de naleving van de plicht om rechtsbescherming jegens plannen en programma's te bieden. Daarbij komt dat het stapelen van procedures door het Hof van Justitie als negatief wordt gezien. In de Zoskupenie II-zaak heeft het Hof van Justitie geoordeeld dat art. 47 van het EU-Handvest in samenhang met art. 9, derde en vierde lid, van het Verdrag zich verzet tegen procesrechtelijke constructies die rechtsbescherming te ingewikkeld maken. ${ }^{36}$ Gesteld kan worden dat exceptieve toetsing een procesrechtelijke constructie is die rechtsbescherming te ingewikkeld maakt, omdat exceptieve toetsing vereist dat wordt opgekomen tegen een nader besluit in plaats van het plan of programma zelf.

\section{Nationaalrechtelijke mogelijkheden}

Zoals reeds aangegeven, staat het een partij c.q. lidstaat vrij hoe rechtsbescherming tegen plannen en programma's te bieden, waarbij het gehele stelsel van rechtsbescherming in een land van belang is. Daarom wordt achtereenvolgens kort stilgestaan bij de strafrechtelijke, bestuursrechtelijke en privaatrechtelijke (on)mogelijkheden naar Nederlands recht, waarbij de bespreking van het privaatrecht zich met name richt op de ontvankelijkheid van een eiser.

\subsection{Bestuursrechtelijk}

In veel gevallen zijn plannen en programma's niet vatbaar voor rechtstreeks bestuursrechtelijk beroep, aangezien ze zijn vervat in een algemeen verbindend voorschrift of zijn geplaatst op de 'negatieve lijst' bij de Algemene wet bestuursrecht (Awb). In dit verband kan worden gedacht aan plannen en programma's ter imple-

34. Zie HvJ EU 21 juli 2016, C-387/15 en C-388/15, ECLI:EU:C:2016:583 (Orléans).

35. HvJ EU 11 april 2013, C-260/11, ECLI:EU:C:2013:221 (Edwards), r.o. 32.

36. Zoskupenie II-uitspraak, r.o. 63. 
mentatie van de KRW en de Richtlijn luchtkwaliteit, met name het Nationaal Samenwerkingsprogramma Luchtkwaliteit (NSL). ${ }^{37}$ Dit is anders voor bijvoorbeeld bestemmingsplannen waartegen op grond van de wet beroep kan worden ingesteld bij de bestuursrechter. ${ }^{38}$ Exceptieve toetsing leidt dan tot vertraging in het bereiken van het doel. Dit geldt te meer in die gevallen waarin geen specifieke besluiten nodig zijn om activiteiten te ontplooien op basis van de plannen en programma's. ${ }^{39}$

Als een plan of programma niet rechtstreeks kan worden voorgelegd, dan kan de bestuursrechter wel een rol hebben. Mede gelet op de betekenis die in Nederland toekomt aan de waterplannen en het NSL, vanwege de indirecte of gecombineerde toetsing, ${ }^{40}$ kunnen waterplannen en het NSL door de bestuursrechter worden onderworpen aan exceptieve toetsing. ${ }^{41}$ Indien een plan of programma in strijd is met een wettelijk voorschrift, dan wel indien het in strijd is met een algemeen rechtsbeginsel, moet een plan of programma buiten toepassing worden gelaten. ${ }^{42}$ In dat geval wordt het plan of programma niet vernietigd door de rechter. Het blijft voor de overige gevallen geldigheid behouden, tenzij het bestuursorgaan zelf tot aanpassing overgaat.

Exceptieve toetsing lijkt op het eerste gezicht wellicht effectiever, omdat de rechtsgevolgen van dat concrete besluit concreet worden voor een belanghebbende. Dit geldt te meer als deze exceptieve toetsing indringender zal zijn dan in het verleden, zoals bepleit door staatsraad advocaat-generaal Widdershoven in zijn conclusie hierover. ${ }^{43}$ Vooralsnog is het de vraag of de huidige

37. Art. 8:5 jo. art. 1, bijlage 2, Awb. Zie ook ABRvS 27 januari 2016, ECLI:NL:RVS:2016:152, AB 2016/238 m.nt. E.J.H. Plambeck.

38. Art. 6:13 en 8:1 Awb in samenhang met art. 8.2 lid 2 onder a Wro.

39. Dit geldt bijv. voor het NSL, maar valt niet zonder meer uit te sluiten voor waterbeheerplannen, zie E.J.H. Plambeck \& L. Squintani, De bescherming en verbetering van de waterkwaliteit in Nederland, of: hoe vertroebeling niet bijdraagt aan een helder begrip en een juiste implementatie van de KRW, M en R 2016, afl. 1, p. 2-14.

40. Voor de waterplannen, zie hierover Plambeck \& Squintani 2016, par. 2.2. J.J.H. van Kempen spreekt in zijn annotatie onder Rb. Rotterdam 17 maart 2017, ECLI:NL:RBROT:2017:2000, M en R 2017/73 over gecombineerde toetsing. Voor het NSL, zie Rb. Den Haag 27 december 2017, ECLI:NL:RBDHA:2017:15380.

41. Voor waterplannen, vgl. ABRvS 25 maart 2015, ECLI:NL:RVS:2015:901, r.o. 10, waar gesproken wordt over exceptieve toetsing van besluiten van algemene strekking, zoals bijv. i.c. een beleidsregel. Voor het NSL, zie Rb. Den Haag 27 december 2017, ECLI:NL:RBDHA:2017:15380. Zie ook ABRvS 10 juni 2015, ECLI:NL:RVS:2015:1837, AB 2015/35 m.nt. W.J. Bosma.

42. De lijn van de Afdeling ten aanzien van exceptieve toetsing lijkt te zijn dat enerzijds algemeen verbindende voorschriften, niet zijnde een wet in formele zin, exceptief getoetst kunnen worden, waarbij dit ertoe kan leiden dat het voorschrift buiten toepassing wordt gelaten of onverbindend wordt verklaard. Denk hierbij bijv. aan bestemmingsplanregels; zie o.m. ABRvS 9 september 2015, ECLI:NL:RVS:2015:2818; AB 2015/439 m.nt. D. Korsse; ABRvS 17 augustus 2016, ECLI:NL:RVS:2016:2235, JM 2016/131 m.nt. J.S. Haakmeester; ABRvS 20 juli 2016, ECLI:NL:RVS: 2016:2015. Anderzijds kunnen besluiten van algemene strekking exceptief worden getoetst, zij het dat deze alleen buiten toepassing kunnen worden gelaten; zie o.m. de in noot 41 aangehaalde jurisprudentie.

43. Conclusie staatsraad A-G Widdershoven bij ABRvS 22 december 2017, 201701963/3/R1 en 201705745/2/A1, ECLI:NL:RVS:2017:3557. terughoudende toetsing voldoende doeltreffend is. ${ }^{44} \mathrm{Zo}$ is het buiten toepassing laten van een plan of programma, laat staan het ongeldig verklaren daarvan, niet snel aan de orde. ${ }^{45}$

Hoewel het mogelijk is om via exceptieve toetsing eventuele procedurele tekortkomingen aan de orde te stellen, stuit dit volgens mij verder nog op drie problemen. Allereerst is een kleinere groep mensen en organisaties belanghebbende bij een specifieke handeling ten opzichte van de groep mensen en organisaties die deel kunnen nemen aan een publieke participatieprocedure in het kader van een plan of programma. Plannen en programma's hebben daarnaast een groter toepassingsgebied dan specifieke besluiten. Zo was het voor eenieder mogelijk om een zienswijze in te dienen bij de vaststelling van het NSL, terwijl tegen een tracébesluit tot uitbreiding van een snelweg die past binnen het NSL slechts belanghebbenden in beroep kunnen. Dit leidt tot een tweedeling van het publiek met betrekking tot rechtsbescherming tussen diegenen die niet in beroep kunnen gaan tegen een concreet besluit gebaseerd op een plan of programma en mogelijk, zoals hierna uiteengezet, bij de civiele rechter het plan of programma kunnen aanvechten, en diegenen die zullen moeten wachten op een concreet besluit.

Dit leidt ten tweede tot tijdsverloop, waardoor rechtsbescherming jegens plannen en programma's als zodanig effectiever lijkt dan exceptieve toetsing voor het beslechten van procedurele kwesties rondom de publieke participatieprocedure ter vaststelling van een plan of programma. Als zulke problemen ontstaan, is het volgens mij effectiever als deze gelijk worden beslecht en niet pas na het nemen van specifieke besluiten. Het tijdsverloop maakt het praktisch niet mogelijk om de publieke participatieprocedure van plannen en programma's over te doen.

Het laatste, maar zeker niet onbelangrijkste probleem ziet op het mogelijke ontbreken van relativiteit, zoals bedoeld in art. 8:69a Awb. Zo is het de vraag of een particulier belang wel binnen het beschermingsbereik van bijvoorbeeld de KRW valt, en om die reden of de strijdigheid van een plan of programma met de KRW wel aan de orde kan komen. ${ }^{46}$

Kortom, de genoemde problemen in relatie tot de Unierechtelijk sterke voorkeur voor het rechtstreeks kunnen

44. Zie ook E.M.H. Hirsch Ballin, Dynamiek in de bestuursrechtspraak, in: E.M.H. Hirsch Ballin e.a., Rechtsontwikkeling door de bestuursrechter (preadviezen VAR, nr. 154), Den Haag: Boom juridisch 2015, p. 7-58; L. van den Berge, Bestuursrecht tussen autonomie en verhouding. Naar een relationeel bestuursrecht (diss. Utrecht), Den Haag: Boom juridisch 2016, p. 271-302.

45. H.J. de Vries, Exceptieve toetsing van algemeen verbindende voorschriften in het omgevingsrecht door de bestuursrechter: de stand van zaken, TO 2017, afl. 4, p. 151-155, en de daarin genoemde voorbeelden toegepast op het omgevingsrecht.

46. Vgl. ABRvS 18 mei 2016, ECLI:NL:RVS:2016:1296, JM 2016/122 m.nt E.J.H. Plambeck, waarin het beroep op de Habitatrichtlijn door een particulier afstuit op het ontbreken van relativiteit. De Afdeling overweegt dat dit niet in strijd is met de Unierechtelijke beginselen van gelijkwaardigheid en doeltreffendheid en het beginsel van effectieve rechtsbescherming als neergelegd in art. $47 \mathrm{EU}-$ Handvest. 
aanvechten van een plan of programma maken dat exceptieve toetsing van plannen of programma's mijns inziens tekortschiet in het licht van het Verdrag en het Unierecht.

\subsection{Strafrechtelijk}

Wat betreft het strafrechtelijk spoor kan worden volstaan met de constatering dat de rechtsbescherming jegens plannen en programma's in het Nederlandse omgevingsrecht niet via deze route wordt geborgd. Het stellen van plannen en programma's is namelijk een exclusieve bevoegdheid van de aangewezen bestuursorganen, die dus immuniteit genieten voor hun handelingen. ${ }^{47}$ Verder geldt dat burgers niet worden vervolgd voor het overtreden van plannen of programma's, waarna de strafrechter al dan niet via exceptieve toetsing een rechtsingang biedt. ${ }^{48}$

\subsection{Privaatrechtelijk}

Als een plan of programma niet rechtstreeks aan de bestuursrechter kan worden voorgelegd, en omdat exceptieve toetsing door de bestuursrechter eigenlijk niet past binnen het Unierecht, kan in theorie de burgerlijke rechter als vangnet fungeren. Echter, de vrij recente uitspraken van zowel de Rechtbank Den Haag als het Gerechtshof Den Haag in het kader van luchtkwaliteitsplannen suggereren dat dit niet zo gemakkelijk kan worden aangenomen.

In de uitspraak van 12 oktober 2016 verklaart de rechtbank een beroep om de onrechtmatigheid van (het gebrek van) een luchtkwaliteitsplan van de gemeente Haren inhoudelijk te beoordelen niet-ontvankelijk. ${ }^{49}$ Twee belangenorganisaties hadden in eerste instantie beroep ingesteld bij de Afdeling tegen de afwijzende beslissing van de gemeente Haren om een plan te maken en handelingen te verrichten om de luchtkwaliteit te verbeteren. De Afdeling had zich onbevoegd verklaard omdat:

'[h] et verzoek van de stichting om naleving van artikel 5.9, eerste lid, van de Wet milieubeheer door vaststelling van een plan (...) een verzoek [is] tot het verrichten van een feitelijke handeling. De inhoudelijke reactie van het college op dat verzoek is daarom evenmin een besluit, zodat daartegen geen bezwaar en beroep openstaan.' 50

De civiele rechter is echter van mening dat in dit geval in theorie exceptieve toetsing door de bestuursrechter mogelijk is. ${ }^{51}$ Daarom acht de civiele rechter eisers in hun vordering op grond van art. 6:162 en 3:305a BW niet-ontvankelijk. In casu ging het over de exceptieve

47. Zie art. 51 Sr; HR 6 januari 1998, NJ 1998/367 en HR 25 januari 1994, NJ 1994/598 (Pikmeer-arresten).

48. Overigens kan m.i. niet worden uitgesloten dat het overtreden van een in een plan of programma opgenomen maatregel strafbaar is krachtens de Wet op de economische delicten.

49. Rb. Den Haag 12 oktober 2016, ECLI:NL:RBDHA:2016:14947.

50. ABRvS 10 december 2014, ECLI:NL:RVS:2014:4493, r.o. 5.

51. Rb. Den Haag 12 oktober 2016, ECLI:NL:RBDHA:2016:14947, r.o. 5.8. toetsing van de rekenmethodiek onder de Regeling beoordeling luchtkmaliteit, die ten grondslag ligt aan de conclusie dat er geen overschrijding is van de grenswaarden uit de Richtlijn luchtkwaliteit en de bepalingen van de richtlijn zelf op dit punt. Een vergelijkbare redenering kan mijns inziens worden toegepast ten aanzien van andere elementen als rekenmethoden.

Dit laat de uitspraak van dezelfde rechtbank van 27 december 2017 zien in een door Milieudefensie aangespannen bodemprocedure. In deze procedure werd het NSL als zodanig aangevochten door twee belangenorganisaties en 57 individuele eisers, die onder meer meenden dat dit programma in strijd is met de Luchtkwaliteitsrichtlijn. De civiele rechter heeft per vordering bezien of de 59 appellanten, individueel gezien, het beoogde materiële resultaat niet konden bereiken met een beroep bij de bestuursrechter. De civiele rechter was van mening dat bijna alle appellanten de theoretische mogelijkheid hebben gehad om op te komen tegen een beschikking waarbij exceptieve toetsing van het NSL mogelijk was, of dat een dergelijke beschikking binnen afzienbare tijd te verwachten is, zodat bijna alle appellanten niet-ontvankelijk werden verklaard. ${ }^{52}$ Het is niet duidelijk wat de rechtbank onder 'binnen afzienbare tijd' verstaat. ${ }^{53}$

Dat het ook anders kan, heeft de voorzieningenrechter van dezelfde rechtbank laten zien. Milieudefensie en de individuele eisers werden in het kort geding tegen het NSL ontvankelijk verklaard, omdat

'[h]et maken van een (deugdelijk) luchtkwaliteitsplan niet het onderwerp [kan] zijn van bestuursrechtelijk bezwaar en beroep. Daarmee is de ontvankelijkheid van Milieudefensie cs in hun vorderingen gegeven. ${ }^{54}$

Helaas ontbeert dit vonnis aan betekenis, omdat in de bodemprocedure de rechtbank uitdrukkelijk anders heeft geoordeeld en in het hoger beroep tegen het vonnis in kort geding het hof uitdrukkelijk overweegt dat er geen reden is om af te wijken van het uitgangspunt dat het vonnis in hoger beroep moet worden afgestemd op een (tussen)vonnis in een bodemprocedure. ${ }^{55}$

Als ook in hoger beroep in de bodemprocedure het vonnis van de rechtbank wordt gevolgd, waarbij de visie wordt aangehangen dat de theoretische mogelijkheid van exceptieve toetsing reeds leidt tot niet-ontvankelijkverklaring van een eiser, dan leidt dit om met Drion te spreken tot 'verongelukken in het recht'. ${ }^{56}$ Ervan uitgaande dat het verkrijgen van een materieel oordeel over een plan of programma via exceptieve toetsing slechts is

52. Rb. Den Haag 27 december 2017, ECLI:NL:RBDHA:2017:15380, AB 2018/115 m.nt. Ch.W. Backes en G.A. van der Veen, o.a. r.o. 4.65-4.67.

53. Vgl. annotatie van Ch.W. Backes \& G.A. van der Veen onder Rb. Den Haag 27 december 2017, ECLI:NL:RBDHA:2017:15380, AB 2018/115.

54. Rb. Den Haag 7 september 2017 (vzr.), ECLI:NL:RBDHA:2017:10171, r.o. 4.2 .

55. Hof Den Haag 22 mei 2018, ECLI:NL:GHDHA:2018:1128, r.o. 6.

56. C.E. Drion, Verongelukken in het recht, NJB 2017/308, die de verschillende uitspraken over het alcoholslotprogramma bespreekt. 
voorbehouden aan belangenorganisaties, omdat aan burgers en bedrijven het relativiteitsvereiste wordt tegengeworpen, dan leidt een succesvol beroep niet tot vernietiging van het plan zelf. In dat geval zal een belangenorganisatie zich alsnog tot de civiele rechter moeten wenden om een bestuursorgaan te gebieden een plan op te stellen conform het Unierecht. ${ }^{57}$ Dit kan mijns inziens niet als een effectieve vorm van rechtsbescherming worden gezien in het licht van de Zoskupenie II-uitspraak. ${ }^{58} \mathrm{De}$ constatering door de rechters in de Milieudefensiebodemprocedure dat de bevoegdheidsverdeling tussen de bestuurs- en de civiele rechter in Nederland een lappendeken is, draagt daar zeker aan bij. ${ }^{59}$ De wijze waarop de voorzieningenrechter invulling heeft gegeven aan de ontvankelijkheidstoets is vanuit internationaal- en Unierechtelijk perspectief mijns inziens de juiste, en verdient dus navolging, in tegenstelling tot de uitspraken in beide bodemprocedures. ${ }^{60}$ Als de civiele rechter deze ontvankelijkheidstoets niet volgt, dan betwijfel ik ten zeerste of het gehele stelsel van rechtsbescherming voldoet aan de eisen die voortvloeien uit het Verdrag en het Unierecht.

\section{Conclusie}

Gelet op de eisen die voortvloeien uit het Verdrag en de Unierechtelijke implementatie daarvan dient rechtsbescherming te worden geboden bij enerzijds besluiten die betrekking hebben op bijlage I-activiteiten en specifieke besluiten en anderzijds plannen en programma's. Daarbij is de inhoud leidend voor de vraag of art. 9, tweede of derde lid, van het Verdrag van toepassing is. Gelet op de Unierechtelijke systematiek en interpretatiemethoden verdient het de voorkeur dat plannen en programma's als zodanig aan de rechter kunnen worden voorgelegd. Mogelijkerwijs is exceptieve toetsing onvoldoende. Nationaalrechtelijk voldoet, gelet daarop, de bestuursrechtelijke weg niet. De strafrechtelijke weg speelt al helemaal geen rol. Rest nog de civielrechtelijke weg, die op zichzelf wel rechtsbescherming kan bieden. Naast de (te) strenge ontvankelijkheidsvereisten, zoals hiervoor uiteengezet, is het echter de vraag of een civielrechtelijke procedure in overeenstemming is met de andere eisen die voortvloeien uit art. 9, vierde lid, van het Verdrag. Zie daarvoor onder meer de bijdragen van Bauw en in het bijzonder Van der Veen in dit nummer, die illustreren dat het niet eenvoudig is om civielrechtelijk plannen en programma's aan de rechter voor te leggen, onder meer vanwege de rol en functie van hoger

57. Vgl. annotatie van Ch.W. Backes onder Rb. Den Haag 7 september 2017 (vzr.), ECLI:NL:RBDHA:2017:10171, AB 2017/335.

58. HvJ EU 8 november 2016, C-243/15, ECLI:EU:C:2016:838 (Zoskupenie II), r.o. 63

59. Rb. Den Haag 27 december 2017, ECLI:NL:RBDHA:2017:15380, AB 2018/115 m.nt. Ch.W. Backes en G.A. van der Veen, r.o. 4.56.

60. Zie ook B.J. van Ettekoven e.a., Overheidsaansprakelijkheid anno 2018 de stand van de rechtsontwikkeling, O\&A 2018/23, die de relevantie van de aanpak als gevolgd in de uitspraak van 27 december 2017 relativeren. beroep in relatie tot het moment van toetsing en mogelijke bewijstechnische perikelen. Ook op andere punten dan in die bijdragen aangegeven voldoet de civielrechtelijke weg niet, waarbij gedacht kan worden aan de bestanddelen van de onrechtmatige daad. De ruimte ontbreekt echter voor een verdere analyse. Kortom, niet valt uit te sluiten dat het Nederlands recht met betrekking tot rechtsbescherming jegens plannen en programma's niet voldoet aan de eisen uit het Verdrag en het Unierecht. $^{61}$
61. Voor de mogelijke gevolgen zij verwezen naar Squintani \& Plambeck 2016. Zie ook S. Biernat e.a., Consequences of Incompatibility with EC Law for Final Administrative Decisions and Final Judgments of Administrative Courts in the Member States, Warsaw: Naczelny Sad Administracyjny 2008. 